\title{
PENERAPAN PEMBELAJARAN SAINTIFIK BERBANTUAN TALKING STICK UNTUK MENGINGKATKAN HASIL BELAJAR SISWA MATERI LUAS BANGUN DATAR KELAS IV SD NEGERI 100 KENDARI
}

\author{
Rima Septiani ${ }^{1)}$, La Ode Kaimudin ${ }^{1)}$, Yoo Eka Yana Kansil ${ }^{1)}$ \\ ${ }^{1)}$ Jurusan Pendidikan Guru Sekolah Dasar \\ FKIP Universitas Halu Oleo \\ email: rymhaseptiani032@gmail.com, laodekaimudint30@gmail.com, yookansil@uho.ac.id
}

\begin{abstract}
Abstrak : Penelitian ini bertujuan meningkatkan hasil belajar siswa pada materi luas bangun datar melalui penerapan pembelajaran saintifik berbantuan Talking Stick di kelas IV SD Ngeri 100 Kendari. Jenis penelitian ini adalah Penelitian Tindakan Kelas (PTK). Prosedur penelitian yaitu: (a) perencanaan (planning), (b) pelaksanaan tindakan (action), (c) observasi dan evaluasi (observation and evaluation), dan (d) refleksi (reflection). Jenis data yaitu data kualitatif dan data kuantitatif. Data kualitatif diperoleh melalui lembar observasi sedangkan data kualitatif melalui tes hasil belajar. Hasil analisis penelitian pada siklus I terdapat 5 siswa yang telah mencapai nilai $\geq 65$ dengan ketuntasan sebesar $78,26 \%$ dan terdapat 18 orang siswa atau $21,73 \%$ yang tidak tuntas, dan nilai rata-rata yang diperoleh siswa adalah 53,04. Siklus II terdapat 20 siswa telah mencapai nilai $\geq 65$ dengan ketuntasan sebesar 86,95\% dan terdapat 3 orang siswa atau 13,04\% yang tidak tuntas, dan nilai rata-rata yang diperoleh siswa tersebut adalah 82,60 .
\end{abstract}

Kata kunci : Pembelajaran Saintifik Berbantuan Talking Stick; Hasil Belajar

\section{IMPLEMENTATION OF SCIENTIFIC LEARNING ASSISTED WITH TALKING STICK TO IMPROVE STUDENTS 'LEARNING OUTCOMES IN CLASS IV PLANE OF SD NEGERI 100 KENDARI}

\begin{abstract}
This study aims to improve student learning outcomes in the material wide flat area through the application of a scientific-based Talking Stick model in class IV SD Terror 100 Kendari. This type of research is Classroom Action Research (CAR). The research procedures are: (a) planning, (b) implementing actions, (c) observation and evaluation, and (d) reflection. The types of data are qualitative data and quantitative data. Qualitative data obtained through observation sheets while qualitative data through tests of learning outcomes. The results of the research analysis in cycle I, there were 5 students who had reached a value of $\geq 65$ with a completeness of $78.26 \%$ and there were 18 students or $21.73 \%$ who did not complete, and the average score obtained by students was 53.04. In cycle II, there were 20 students who had reached a value of $\geq 65$ with a completeness of $86.95 \%$ and there were 3 students or $13.04 \%$ who did not complete, and the average score obtained by these students was 82.60 .
\end{abstract}

Keywords: Scientific Learning Assisted by Talking Stick; Learning Outcomes 


\section{Pendahuluan}

Pendidikan merupakan suatu aspek kehidupan yang sangat mendasar bagi pembangunan bangsa dalam suatu negera. Dalam penyelenggaraan pendidikan di sekolah sebagai lembaga pendidikan formal melibatkan guru sebagai pendidik dan siswa sebagai peserta didik yang diwujudkan dalam suatu proses pembelajaran. Dalam ruang lingkup penyelenggaraan pendidikan ini, guru dengan sadar merencanakan kegiatan pembelajaran secara sistematis dan berpedoman pada seperangkat aturan yang dikemas dalam bentuk kurikulum.

Dalam proses pengajaran, unsur proses belajar memegang peranan penting dalam menentukan bagaimana hasil belajar siswa. Mengajar diartikan sebagai suatu keadaan atau suatu aktivitas untuk menciptakan suatu situasi yang mampu mendorong siswa untuk belajar. Situasi ini tidak harus berupa transformasi pengetahuan dari guru kepada siswa saja, akan tetapi dapat dengan cara lain misalnya belajar melalui media pembelajaran yang sudah disiapkan. Maka, dalam pembelajaran situasi atau kondisi yang memungkinkan terjadinya proses belajar harus dirancang dan dipertimbangkan terlebih dahulu oleh guru. (Aunurrahman, 2011:34)

Proses pembelajaran menuntut adanya partisipasi aktif dari seluruh siswa. Jadi kegiatan pembelajaran berpusat pada siswa, guru sebagai motivator dan fasilitator agar suasana kelas menjadi lebih hidup. Bila melihat tujuan pendidikan di Sekolah Dasar maka sasarnnya adalah menghasilkan lulusan yang berkompeten, cerdas, dan berkualitas sehingga mampu dan proaktif menjawab tantangan pendidikan yang lebih tinggi. Tujuan itu terus diupayakan akan tetapi tidak sesuai dengan harapan. Masalah utama yang menjadi kendala adalah rendahnya hasil belajar siswa.

Berdasarkan hasil observasi pra penelitian yang dilakukan peneliti di kelas IV SD Negeri 100 Kendari pada tanggal 25 November 2019, menemukan permasalahn yaitu pada hasil belajar matematika siswa. Melalui pembicaraan singkat dengan guru kelas IV ditemukan bahwa data hasil belajar siswa pada mata pelajaran Matematika, khususnya materi Luas Bangun Datar, di kelas IV SD Negeri 100 Kendari, pada nilai semester 2 tahun ajaran 2018/2019 dari 18 siswa hanya 7 orang siswa yang mendapat nilai $\geq 65$ atau $38,88 \%$. Nilai ini belum mencapai Kriteria Ketuntasan Minimal (KKM) yang ditetapkan oleh sekolah yaitu 65 atau mencapai minimal $80 \%$.

Dari hasil pengamatan tersebut, maka peneliti sebagai calon guru mencoba merefleksikan masalah yang diperoleh dengan pengalaman peneliti sebagai mahasiswa dan calon guru. Peneliti menyadari bahwa guru yang bersangkutan lebih perpengalaman dalam hal belajar mengajar dalam kelas dibandingkan dengan peneliti sebagai calon guru. Oleh karena itu, peneliti sebagai calon guru mencoba memperbaiki kinerja sebagai wawasan yang akan digunakan dimasa yang akan datang. Dengan demikian, salah satu tindakan alternatif yang harus dilakukan adalah melaksanakan Penelitian Tindakan Kelas (PTK). Oleh karena itu, perlu pemilihan dan penerapan model pembelajaran tertentu yang dapat mengaktifkan siswa secara keseluruhan sekaligus mengembangkan aspek kepribadian seperti kerja sama, tanggung jawab dan disiplin.

Oleh karena itu peneliti merasa tertantang untuk menggunakan model pembelajaran Cooperative tipe Talking Stick dalam menerapkan pembelajaran saintifik untuk meningkatkan hasil belajar siswa pada materi luas bangun datar. Alternatif ini dimaksudkan untuk meningkatkan hasil belajar siswa. Pembelajaran saintifik berbantuan Talking stick dapat digunakan untuk meningkatkan hasil belajar siswa karena berdasarkan kenyataan yang ada bahwa salah satu karakteristik anak siswa SD adalah masih senang bermain.

Talking stick berbasis saintifik juga pernah dibuktikan oleh Linda Antari (2016) dalam penelitiannya yang berjudul Linda Antari (2016) dalam penelitiannya yang berjudul "Penerapan Talking Stick Dengan Pendekatan Saintifik Untuk Meningkatkan Keaktifan Dan Penguasaan Kompetensi Pengetahuan IPA siswa kelas VA SD Negeri 10 Pemecutan”. Kemudian menunjukan peningkatan pada hasil belajar siswa 
Model yang dapat diterapkan yaitu model talking stick karena karakteristik yang dimiliki oleh model Talking Stick yang interaktif, menantang siswa untuk dengan cepat menguasai materi pembelajaran, memotivasis siswa untuk berpartisipasi aktif dalam memberikan masukan berdiskusi dan menjawab soal cocok dipadukan dengan pendekatan saintifik. Sehingga diterapkannya model Talking Stick dapat membuat siswa tertarik, tertantang dan memiliki rasa tanggung jawab untuk menemukan pengetahuannya sendiri terutama dalam mendalami materi yang diberikan guru. Dengan diberinya kesempatan berbicara pada siswa maka keberanian serta rasa percaya diri siswa akan muncul. Pendekatan saintifik merupakan pendekatan yang mengutamakan kreativitas dan temuan-temuan siswa di dalam kegiatan pembelajaran (Kosasih,2015:72).

Dari uraian permasalahan di atas, maka penulis tertarik melakukan penelitian dengan judul "Penerapan Pembelajaran Saintifik Berbantuan Talking Stick Untuk Mengingkatkan Hasil Belajar Siswa Materi Luas Bangun Datar Kelas IV SD Negeri 100 Kendari"

\section{Metode Penelitian}

Jenis penelitian yang digunakan dalam penelitian ini adalah penelitian tindakan kelas (PTK) Penelitian tindakan kelas.Penelitian ini dilaksanakan di kelas IV SD Negeri 100 Kendari yang berlokasi di Kel. Kambu, Kec. Kambu Kota Kendari Provinsi Sulawesi Tenggara pada semester II tahun ajaran 2019/2020. Subjek penelitian ini adalah siswa dan guru kelas IV SD Negeri 100 Kendari yang berjumlah 23 orang siswa yang terdiri dari 9 orang siswa perempuan dan 14 orang siswa laki-laki. Penelitian tindakan kelas ini dilaksanakan dalam 2 (dua) siklus. Adapun prosedur penelitian tindakan ini meliputi: (1) Perencanaan, (2) PelaksanaanTindakan, (3) Observasi dan Evaluasi, dan (4) Refleksi dalam setiap siklus. Jenis data yaitu data kualitatif dan data kuantitatif.Data kualitatif diperoleh melalui observasi, menggunakan lembar observasi sedangkan data kuantitatif diperoleh melalui tes setiap akhir siklus tindakan.Analisis data yang digunakan dalam penelitian ini terbagi dua yaitu analisis kualitatif dan analisis kuantitatif. Data kualitatif akan dianalisis ecara deskriptif kualitatif berdasarkan hasil observasi yang dilakukan. Sedangkan data kuantitatif dianalisis secara kuantitatif berdasarkan hasil tes pada setiap akhir siklus tindakan.

\section{Hasil Penelitian}

1. Aktivitas Guru

Berdasarkan hasil observasi dan evaluasi pada aktivitas mengajar guru yang dilakukan peneliti dapat dilihat pada Tabel 1 berikut :

Tabel 1. Skor Aktivitas Guru dalam Pelaksanaan Proses Pembelajaran dengan Menerapkan Model Pembelajaran Talking Stick Berbasis Saintifik Pada Siklus I dan Siklus II

\begin{tabular}{llll}
\hline No & \multicolumn{1}{c}{ Aspek yang diamati } & & Skor/Siklus \\
\hline I & Kegiatan Awal & I & II \\
\cline { 2 - 4 } & 1. Mengkondisikan kelas & 4 & 4 \\
\hline & 2. Melakukan apersepsi & 4 & 4 \\
\hline 3. Memotivasi siswa untuk belajar & 3 & 3 \\
\hline 4. Menyampaikan tujuan pembelajaran & 2 & 3 \\
\hline Kegiatan Inti & & 4 \\
\hline $\begin{array}{l}\text { Menjelaskan materi bangun datar } \\
\text { kepada siswa }\end{array}$ & 4 & 4 \\
\hline $\begin{array}{l}\text { Mengkoordinasikan siswa kedalam } \\
\text { kelompok yang beranggotakan 4-5 } \\
\text { orang secara heterogen }\end{array}$ & 4 & \\
\hline
\end{tabular}




\begin{tabular}{|c|c|c|c|}
\hline \multirow[t]{2}{*}{ No } & Aspek yang diamati & \multicolumn{2}{|c|}{ Skor/Siklus } \\
\hline & $\begin{array}{l}\text { 3. Memberikan kesempatan kepada } \\
\text { siswa untu menanyakan materi yang } \\
\text { belum dipahami }\end{array}$ & 3 & 3 \\
\hline & $\begin{array}{l}\text { 4. Membagikan LKPD kepada masing- } \\
\text { masing kelompok untuk didiskusikan }\end{array}$ & 4 & 4 \\
\hline & $\begin{array}{l}\text { 5. Membimbing siswa mengerjakan } \\
\text { soal dalam LKPD }\end{array}$ & 4 & 4 \\
\hline & $\begin{array}{llr}\text { 6. } & \text { Menugaskan } & \text { kelompok } \\
\text { mempresentasekan hasil diskusi } \\
\text { kelompoknya dan kelompok lain } \\
\text { menanggapi }\end{array}$ & 4 & 4 \\
\hline & $\begin{array}{l}\text { 7. Memimpin jalannya permainan } \\
\text { (Talking Stick) }\end{array}$ & 4 & 4 \\
\hline & 8. memberi arahan tata cara permainan & 4 & 4 \\
\hline & $\begin{array}{l}\text { 9. Menentukan siswa dengan skor } \\
\text { tertinggi disetiap kelompok }\end{array}$ & 4 & 4 \\
\hline & $\begin{array}{l}\text { 10. Memberikan penghargaan kepada } \\
\text { siswa dengan skor tertinggi }\end{array}$ & 4 & 4 \\
\hline III & Kegiatan Akhir & & \\
\hline & $\begin{array}{l}\text { 1. Membantu siswa menyimpulkan } \\
\text { materi yang telah dipelajari }\end{array}$ & 4 & 4 \\
\hline & 2. Memberikan refleksi & 4 & 4 \\
\hline & Jumlah & 60 & 61 \\
\hline & Persentase & $93,75 \%$ & $95,31 \%$ \\
\hline
\end{tabular}

Berdasarkan data hasil observasi di atas, menunjukan bahwa hasil data pengamatan aktivitas guru siklus I pertemuan I diperoleh skor 60 atau dengan persentase 93,75\% sedangkan pada pertemuan II diperoleh peningkatan skor menjadi 61 dengan persentase 95,31\% .

\section{Aktivitas Siswa}

Berdasarkan hasil observasi dan evaluasi pada aktivitas pembelajaran siswa yang dilakukan peneliti dapat dilihat pada Tabel 2 berikut :

Tabel 2. Skor Aktivitas Siswa dalam Mengikuti Kegiatanan Pembelajaran dengan Menerapkan Model Pembelajaran Talking Stick Berbasis Saintifik Pada Siklus I dan Siklus II

\begin{tabular}{|c|c|c|c|}
\hline No & Aspek yang diamati & \multicolumn{2}{|c|}{ Skor/Siklus } \\
\hline $\mathbf{I}$ & Kegiatan Awal & $\mathbf{I}$ & II \\
\hline & $\begin{array}{l}\text { 1. Mendengarkan arahan guru } \\
\text { mengkondisikan kelas }\end{array}$ & 3 & 3 \\
\hline & 2. Memperhatikan ketika guru melakukan apersepsi & 4 & 4 \\
\hline & $\begin{array}{l}\text { 3. Keterlibatan dalam membangkitkan motivasi } \\
\text { untuk belajar }\end{array}$ & 2 & 3 \\
\hline & $\begin{array}{l}\text { 4. Memperhatikan dan menyimak saat guru } \\
\text { menyampaikan tujuan pembelajaran }\end{array}$ & 2 & 3 \\
\hline II & Kegiatan Inti & & \\
\hline & 1. Memperhatikan penjelasan guru & 3 & 3 \\
\hline
\end{tabular}




\begin{tabular}{|c|c|c|c|}
\hline \multirow[t]{2}{*}{ No } & Aspek yang diamati & \multicolumn{2}{|c|}{ Skor/Siklus } \\
\hline & $\begin{array}{l}\text { 2. Membentuk kelompok sesuai dengan petunjuk } \\
\text { guru }\end{array}$ & 3 & 3 \\
\hline & $\begin{array}{l}\text { 3. Antusias untuk bertanya seputaran materi yang } \\
\text { kurang dipahami }\end{array}$ & 2 & 2 \\
\hline & 4. Mengerjakan LKS yang dibagikan oleh guru & 4 & 4 \\
\hline & 5. Berdiskusi dalam kelompok & 2 & 2 \\
\hline & 6. Mempersentasekan hasil diskusi kelompoknya & 4 & 4 \\
\hline & 7. Persiapan melakukan permainan(Talking Stick) & 4 & 4 \\
\hline & 8. $\quad$ Bermain secara sehat dan jujur & 3 & 3 \\
\hline & 9. Menghargai pendapat teman & 3 & 3 \\
\hline & 10. Menerima penghargaan & 4 & 4 \\
\hline III & Kegiatan Akhir & & \\
\hline & 1. Menyimpulkan materi yang telah dipelajari & 2 & 2 \\
\hline & $\begin{array}{l}\text { 2. Menanggapi evaluasi atau refleksi yang diberikan } \\
\text { oleh guru }\end{array}$ & 3 & 3 \\
\hline & Jumlah & 48 & $\mathbf{5 0}$ \\
\hline & Persentase & $75 \%$ & $78,12 \%$ \\
\hline
\end{tabular}

Berdasarkan data hasil observasi (terlampir), menunjukan bahwa hasil data pengamatn aktivitas siswa siklus 1pertemuan I diperoleh skor 48 atau dengan persentase $75 \%$ sedangkan pada pertemuan II diperoleh peningkatan skor menjadi 50 dengan persentase 78,12\%. Untuk lebih jelasnya, persentase aktivitas guru dan siswa pada siklus I disajikan dalam tabel berikut: Tabel 3. Persentase Aktivitas Guru dan Siswa Pada Siklus I

\begin{tabular}{llccc}
\hline No & Aspek Pengamatan & $\begin{array}{c}\text { Jumlah skor } \\
\text { perolehan }\end{array}$ & $\begin{array}{c}\text { Jumlah skor } \\
\text { maksimum }\end{array}$ & Persentase(\%) \\
\hline 1 & $\begin{array}{l}\text { Aktivitas guru } \\
\text { Pertemuan pertama }\end{array}$ & 60 & 64 & $93,75 \%$ \\
\hline 2 & $\begin{array}{l}\text { Aktivitas guru } \\
\text { Pertemuan Kedua }\end{array}$ & 61 & 64 & $95,31 \%$ \\
\hline 3 & $\begin{array}{l}\text { Aktivitas Siswa } \\
\text { Pertemuan pertama }\end{array}$ & 48 & 64 & $75 \%$ \\
\hline 4 & $\begin{array}{l}\text { Aktivitas siswa } \\
\text { Pertemuan Kedua }\end{array}$ & 50 & 64 & $78,12 \%$ \\
\hline
\end{tabular}

\section{Hasil Belajar}

Hasil analisis penelitian pada siklus I terdapat 5 siswa yang telah mencapai nilai $\geq 65$ dengan ketuntasan sebesar 78,26\% dan terdapat 18 orang siswa atau 21,73\% yang tidak tuntas, dan nilai rata-rata yang diperoleh siswa adalah 53,04. Siklus II terdapat 20 siswa telah mencapai nilai $\geq 65$ dengan ketuntasan sebesar 86,95\% dan terdapat 3 orang siswa atau 13,04\% yang tidak tuntas, dan nilai rata-rata yang diperoleh siswa tersebut adalah 82,60 . 
Tabel 4. Daftar Nilai Hasil Belajar Siswa Siklus I dan Siklus II

\begin{tabular}{lcc}
\hline \multirow{2}{*}{ Pencapaian } & \multicolumn{2}{c}{ Siklus } \\
\cline { 2 - 3 } & I & II \\
\hline Jumlah Siswa & 23 Orang & 23 Orang \\
\hline Nilai Tertinggi & 70 & 100 \\
\hline Nilai Terendah & 20 & 60 \\
\hline Nilai Rata-Rata & 53,04 & 82,60 \\
\hline \% Tuntas & 21,73 & 86,95 \\
\hline \% Tindak Tuntas & 78,26 & 13,04 \\
\hline
\end{tabular}

Berdasarkan hasil uraian pada siklus I dan II, menunjukan bahwa penerapan pembelajaran saintifik berbantuan Talking Stick dapat meningkatkan hasil belajar siswa. Hal ini dapat tercapai karena dalam proses pembelajaran karena siswa sudah bisa bekerja sama dengan kelompok masing-masing, siswa aktif menjawab pertanyaan yang diberikan guru, siswa sudah siap menjawab beberapa pertanyaan tanpa ada ketegangan, siswa tidak lagi bermain dalam prroses pembelajaran namun memusatkan perhatian pada pembelajaran yang sedang berlangsung, Selain itu siswa juga terlibat langsung dalam proses pembelajaran saintifik berbantuan Talking Stick ,mulai tahapan persiapan, pelaksanaan model, kegiatan kelompok, evaluasi dan penghargaan.

\section{Pembahasan}

Berdasarkan hasil evaluasi pada siklus I terhadap hasil belajar siswa menunjukan bahwa dengan melaksanakan pembelajaran saintifik berbantuan Talking Stick dapat meningkatkan hasil belajar siswa pada materi luas bangun datar (persegi, persegi panjang, dan segitiga) di kelas IV SD Negeri 100 Kendari jika dibandingakan dengan hasil belajar siswa tahun ajaran sebelumnya (2018/ 2019).

Peningkatan hasil belajar pada siklus I menunjukan bahwa yang mencapai ketuntasan belajar pada siklus I berumlah 5 orang siswa dengan persentase 78,26 \% sedangkan jumlah siswa yang tidak tuntas sebanyak 18 orang siswa dengan persentase sebesar $21,73 \%$ dengan nilai ratarata yang diperoleh siswa adalah 53,04. Maka, hasil belajar siswa belum mencapai ketuntasan belajar. Meskipun hasil belajar rata-rata secara klasikal meningkat namun memenuhi indikator kinerja sebesar $80 \%$.

Selanjutnya peningkatan hasil belajar siswa meningkat pada siklus II untuk lebih jelasnya peningkatan hasil belajar siswa dapat dilihat pada gambar 2 berikut ini: 


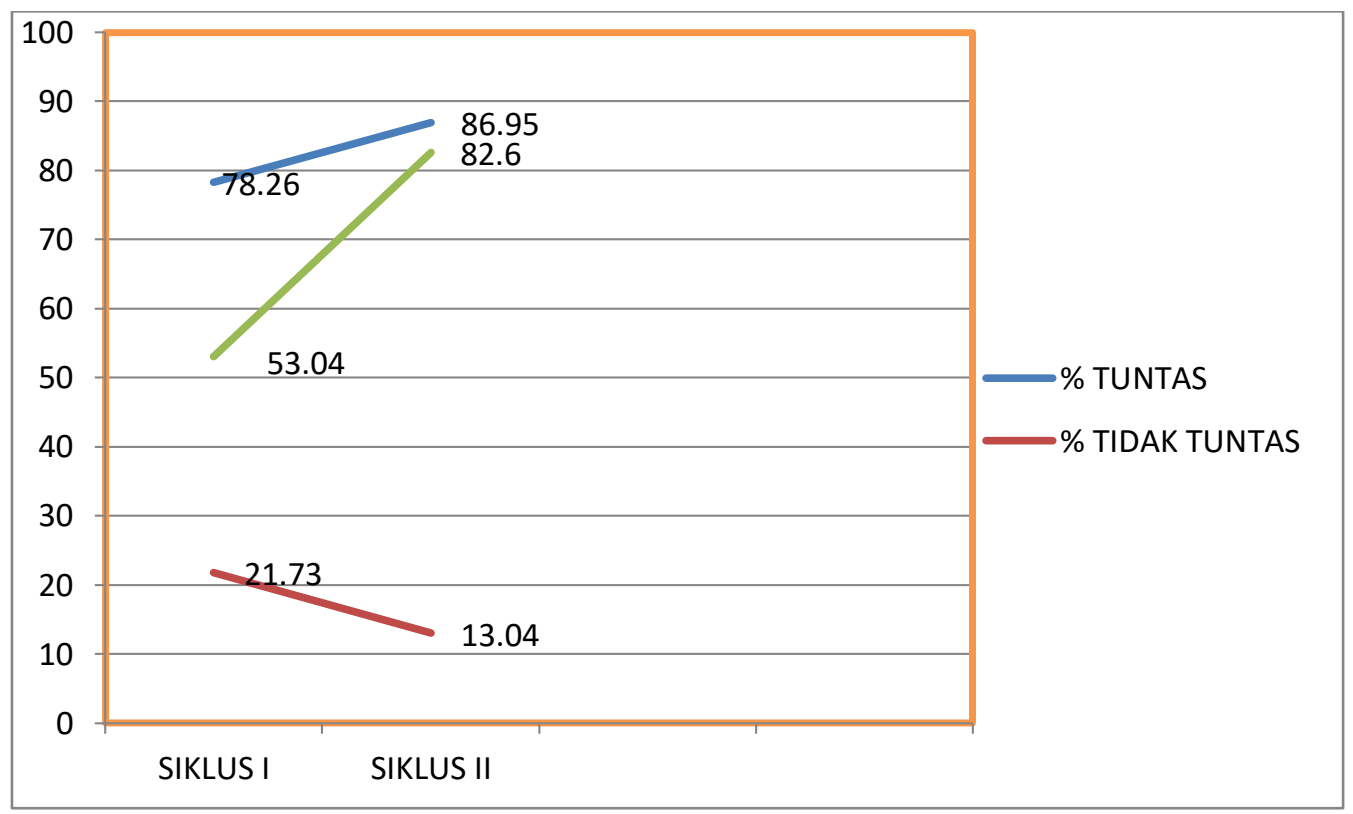

Berdasarkan gambar di atas menunjukan bahwa hasil belajar siswa dalam kegiatan pembelajaran mengalami peningkatan pada siklus II. Siswa yang mencapai ketuntasan berjumlah 20 orang dengan persentase ketuntasan sebesar $86,96 \%$ dan siswa yang tidak mencapai ketuntasan berjumlah 3 orang siswa persentase sebesar 13,04\% dengan nilai rata-rata siswa 82,60. Dari hasil belajar siswa pada siklus II dapat diketahui bahwa indikator kinerja yang telah ditentukan yaitu $80 \%$ telah tercapai, sedangkan hasil observasi kegiatan pembelajaran sudah terlaksana dengan baik sesuai dengan langkah-langkah pembelajaran saintifik berbantuan Talking Stick di kelas IV SD Negeri 100 Kendari.

Berdasarkan hal tersebut, ternyata pembelajaran dengan menerapkan pembelajaran saintifik berbantuan Talking Stick dapat meningkatkan keaktifan dan penguasaan kompetensi pengetahuan siswa kelas IV SD Negeri 100 Kendari . Hal ini terlihat dari kegiatan yang dilakukan siswa dalam pembelajaran seperti siswa sudah mampu untuk aktif, dapat mengemukakan ideidenya saat diberi pertanyaan, antusias dalam mengikuti pembelajaran karena belajar dalam kelompok dan dituntut untuk memahami materi terlebih dahulu sebelum diberi pertanyaan, mampu bekerjasama dengan kelompok, dan berani mengajukan pertanyaan kepada guru maupun teman kelompoknya. Nelson, Gallagher dan Coleman di Azizinehad dalam (Meganingtyas, Winarni, \& Murwaningsih, 2019) menunjukkan bahwa pembelajaran kooperatif dapat menjadi yang terbaik pilihan untuk semua siswa karena dapat meningkatkan interaksi antar siswa, meskipun kompetensinya dan latar belakang.

Berdasarkan teori yang telah dipaparkan sebelumnya, pendekatan saintifik menuntut siswa untuk secara aktif tahapan mengamati, merumuskan masalah, mengajukan hipotesis, mengumpulkan data, menganalisis data, menarik kesimpulan dan mengkomunikasikan konsep yang ditemukan (Daryanto,2014:51). Pendekatan saintifik yang diterapkan dalam kurikulum 2013 dapat meningkatkan kemampuan siswa dalam menyelesaikan masalah secara sistematis,bukan hanya sebatas kira-kira melainkan sesuai dengan fakta yang ditemukan. Untuk mendukung hal tersebut, pendekatan saintifik dipadukan dengan berbagai teknik ataupun model pembelajaran yang tepat salah satunya dengan model pembelajaran Talking Stick. Penerapan Talking Stick dalam pembelajaran memberikan kesempatan kepada siswa untuk mengemukakan ide atau pendapatnya setelah mempelajari materi pembelajaran. Dengan demikian, siswa tidak akan hanya menerima penjelasan guru saja, namun siswa dapat aktif untuk mengemukakan pendapatnya dengan cara 
yang menyenangkan yaitu dengan terlebih dahulu menggilir tongkat. Terciptanya suasana yang menyenangkan membuat siswa tidak jenuh saat belajar dan dapat membuat siswa lebih fokus dalam mengikuti pembelajaran. Siswa akan lebih memahami materi yang dipelajari karena belajar dengan teman dalam kelompoknya dan diberi penguatan terhadap meteri yang dipelajari dengan menanyakan kembali terkait materi yang telah dipelajari. Dengan mencari tahu sendiri melalui berbagai cara, kemampuan siswa mengingat materi tersebut akan lebih lama. Maka dari itu, penerapan pembelajaran saintifik berbantuan Talking Stick tepat diterapkan pada pembelajaran guna mewujudkan pembelajaran yang menyenangkan, berkesan dan bermakna, yang nantinya akan berpengaruh pada keaktifan belajar siswa dan peningkatan prestasi belajar siswa yang dalam hal ini khususnya penguasaan kompetensi matematika siswa.

Keberhasilan dari penelitian ini juga didukung oleh hasil penelitian dari Linda Antari (2016) yang menyatakan bahwa dengan melaksanakan pembelajaran dengan model Talking Stick berbasis pendekatan saintifik dapat meningkatkan keaktifan dan hasil belajaar siswa. Kosasih (2015:101) juga menyatakan salah satu karakteristik Kurikulum 2013, cenderung menghendaki agar proses pembelajarannya dilakukan dengan cara berkelompok. Selain itu model pembelajaran tipe kooperatif akan melatih siswa untuk dapat bekerjasama dalam menyelesaikan suatu masalah. Sehingga penggunaan model Talking Stick dapat dikolaborasikan dengan pendekatan saintifik yang terdapat dalam Kurikulum 2013.

Oleh karenanya hipotesis yang diajukan yaitu Penerapan Pembelajaran Saintifk Berbantuan Talking Stick dapat meningkatkan hasil belajar siswa pada materi luas bangun datar di kelas IV SD Negeri 100 Kendari dapat diterima.

\section{Simpulan}

1. Penerapan pembelajaran sanitifik berbantuan Talking Stick dapat meningkatkan hasil belajar siswa pada materi luas bangun datar. Hal ini dapat ditunjukan oleh hasil tes siklus, nilai rata-rata siswa pada siklus I yaitu 53,04 mengalami peningkatan pada siklus II dengan nilai rata-rata 82,60 dengan persentase ketuntasan siswa pada siklus I hanya 78,26 \% dengan jumlah siswa yang tuntas 5 orang dari 23 orang siswa kemudian meningkat menjadi $86,95 \%$ pada siklus II dengan jumlah siswa yang tuntas mencapai 20 orang dari 23 orang siswa.

2. Penerapan pembelajaran sanitifik berbantuan Talking Stick dapat meningkatkan aktivitas belajar siswa pada materi luas bangun datar. Hal ini dapat ditunjukan oleh hasil observasi aktivitas belajar siswa. Aktivitas belajar isswa pada siklus I mengajar pertamayaitu $75 \%$ meningkat menjadi 78,12 pada mengajar kedua. Kemudian pada siklus II mengajar pertama $84,37 \%$ meningkat menjadi 90,62\% pada mengajar kedua.

3. Penerapan pembelajaran sanitifik berbantuan Talking Stick dapat meningkatkan aktivitas mengajar guru pada meteri luas bangun datar. Hal ini dapat ditunjukan oleh hasil observasi aktivitas mengajar guru. Aktivitas mengajar guru pada siklus I mengajar pertama yaitu 93,75\% meningkat menjadi 95,31 pada mengajar kedua. Kemudian pada siklus II mengajar pertama 96,87\% meningkat menjadi $100 \%$ pada mengajar kedua. 
Jurnal Ilmiah Pembelajaran Sekolah Dasar

Volume 2 Nomor 1 - Februari 2020, e-ISSN 2656-0402

Available online at:http://ojs.uho.ac.id/index.php/jipsd

\section{Daftar Pustaka}

Anurrahman. (2011). Belajar dan Pembelajaran. Bandung: Penerbit Alfabeta.

Asri, B. W., Nurhalim, K., \& Suhandini, P. (2019). The Implementation of Talking Stick Model Assisted by Audio-Visual Media Toward Positive Character and Learning Outcome. 8(15), 225-231.

Kosasih. (2013). Strategi Belajar dan Pembelajaran Implementasi Kurikulum 2013. Bandung: Yrama Widya.

Meganingtyas, B. R., Winarni, R., \& Murwaningsih, T. (2019). The Effect of Using Course Review Horay and Talking Stick Learning Methods Towards Social Science Learning Result Reviewed From Learning Interest. 0-7.

Ni Made Dwi Desiari Putri1, I Ketut Ardana2, I. K. A. P. (2016). Penerapan Talking Stick Berbasis Pendekatan Saintifik Untuk Meningkatkan Pengetahuan IPA Siswa Kelas V SD. E-Journal PGSD Universitas Pendidikan Ganesha Jurusan PGSD, 4(1), 1-11.

NOVIDA, I. (2018). Penerapan Model Talking Stick untuk Meningkatkan Hasil Belajar IPS Pada Materi Jasa dan Peranan Tokoh Pejuang dalam Memproklamasikan Kemerdekaan Indonesia pada Siswa Kelas V SD Negeri 20 Meulaboh Kabupaten Aceh Barat. Bina Gogik: Jurnal Ilmiah Pendidikan Guru Sekolah Dasar, 3(1), 1-14.

Pt, N., Antari, L., Suadnyana, I. N., Ngr, D. B. K., \& Putra, S. (2016). Penerapan Talking Stick Dengan Pendekatan Saintifik Kompetensi Pengetahuan IPA Jurusan Pendidikan Guru Sekolah Dasar , FIP Universitas Pendidikan Ganesha e-Journal PGSD Universitas Pendidikan Ganesha. 4(1), 1-11.

Rufinah, S. (2018). Effect of Number Head Together and Talking Stick Types of Cooperative Learning Model on Redoks Towards Student's Motivation and Learning Outcomes. 174(Ice 2017), 447-451.

Series, C. (2019). Effect of cooperative learning model type of talking stick against student learning Effect of cooperative learning model type of talking stick against student learning. https://doi.org/10.1088/1742-6596/1339/1/012083

Syahrir. (2019). Penggunaan Pendekatan Pembelajaran Saintifik Dalam Meningkatkan Hasil Belajar Matematika Siswa. Jurnal Ilmiah Mandala Education, 5(2), 1-6.

Thobroni, M. (2011). Belajar dan Pembelajaran. Jogjakarta: Ar-Ruzz Media.

Wahyuni, S., Kundera, I. N., \& Gagaramusu, Y. (n.d.). Jurnal Kreatif Tadulako Online Vol . 1 No . 1 ISSN 2354-614X Penerapan Metode Talking Stick untuk Meningkatkan Hasil Belajar IPA Kelas IV di SDN 2 Posona Jurnal Kreatif Tadulako Online Vol . 1 No . 1 ISSN 2354-614X. I(1), 64-76. 